\title{
Looking for Light on the Dark Side of the American Dream- Exploring the Painful Legacy of Nuclear Colonialism in Paradise
}

\author{
A Rowan Gard \\ Centre for Pacific Studies, University of St Andrews, United Kingdom
}

\begin{abstract}
It is estimated that in the last thirty years over 30\% of Micronesians, or some 75,000 individuals, have immigrated to Hawai ' $i$, Guam and the United States (US) mainland in accord with the Compact of Free Association (COFA). The reasons vary but nearly always revolve around the desire for a better life-yet running beneath these individual and family migration histories is the undeniable nuclear legacy of the US military in Micronesia. From 1946 through 1958 the US dropped 109 megatons of munitions, releasing radiation equivalent to more than 7,000 Hiroshima-sized bombs in the Marshall Islands, which has resulted in uninhabitable atolls and extreme environmental degradation in the region. These environmental conditions have been further exacerbated by climate change, in the forms of rising sea-levels and resulting comprised freshwater lenses, destructive storms and extreme droughts.

This article seeks to explore the motivational factors pushing and pulling many Pacific Islanders to and from their homes in Micronesia, as well as the discrimination and harsh economic realities, such as homelessness, they encounter when arriving in the Aloha State.

There is limited awareness in the US and international circles of these newest Americans and the immense challenges they face. Consequently, this article seeks to add to the burgeoning body of understanding on this complex issue, highlight the hard-won successes of all those impacted by COFA, while considering the rising rates of income inequality amid the ongoing homeless crisis in the US and calls on Congress to further support those that continue to live with the painful legacy of nuclear colonialism in the Pacific.
\end{abstract}

Keywords : Compact of Free Association (COFA), Hawai 'i, Homeless, Micronesia, Nuclear testing

\section{Sleeping Rough in Paradise}

In large purple letters, taller than I am- "No Aloha for the Homeless?"-is sprayed across the side of a shipping container in the parking lot of the CVS Pharmacy on South King Street, just next to the green expanse of Mo'ili'ili Neighbourhood Park. This is a sunny Friday in October of 2015, one month after I had returned to Honolulu following three years working abroad, and on this particular Friday the Hawai'i State Governor David Ige declares a State of Emergency (SOE) in response to the growing homeless crisis in Honolulu. This SOE will stretch through to the end of February 2016 with the intent of enabling the State of Hawai' $i$, the only state to require such action, increased flexibility in responding to the crisis. The declaration frees $\$ 1.3$ million for assistance and service mechanisms that promote permanent housing, with $\$ 750,000$ being put toward temporary shelter for families [1]. "We are making sure that we have options for those who are homeless to move into an emergency shelter, and the biggest deficit in the system is shelter space for families," Governor Ige shares; "So the emergency proclamation would allow us to stand up shelters for families in an expeditious manner" [2]. Troublingly, Hawai' $i$ had seen a $23 \%$ recorded increase in its unsheltered homeless population from 2014 to 2015 , with a $46 \%$ recorded increase in the number of unsheltered families [2]. In January of 2016 a homeless point-in-time count placed the figure at 7,921 on the streets of Hawai'i, which also reflects the highest rate of homelessness per capita of any state in the US [3]. The homeless crisis is by no means Hawai'i's alone, the West Coast of the US, including Washington, Oregon and California, have a total homeless population of at least 168,000 as of November 2017 which reflects an increase of some 19,000 people from 2016 [4].

Having a full and accurate understanding of the homeless population in Honolulu — or indeed any urban centre-is challenging, and some I spoke with in support services suggested the count was as much as 50\% underestimated. Yet, regardless of the technical accuracy of the point-in-time statistics, 
the data does reflect a 25\% increasing trend in the homeless population from 2009-2016 [3]. To consider this from another perspective, the homeless population in Hawai' $i$ stands at 487 homeless individuals per 100,000 people - the nation's highest, followed by New York and Nevada, according to federal statistics $[3,5]$. And while there are shelters and a number of resources in place to help the homeless, there are simply far fewer available beds than are needed. For example, about 550 beds are available on any given night on $\mathrm{O}^{\prime}$ ahu, where an estimated 4,940 homeless people live [5]. Statistics are one means of attempting to grasp this new, troubling "normal" in Hawai'i. However, without consulting the statistics it was self-evident that a human crisis was playing out on the streets of Honolulu. One evening in November of 2015 as I was walking to a meeting at McKinley High School on South King Street, I passed twenty-two individuals sleeping on the street in a single mile-long stretch. This was not the Hawai'i I remembered. And in the following weeks, and now years, it has been that giant purple question mark in the "No Aloha for the Homeless?" that has stayed with me.

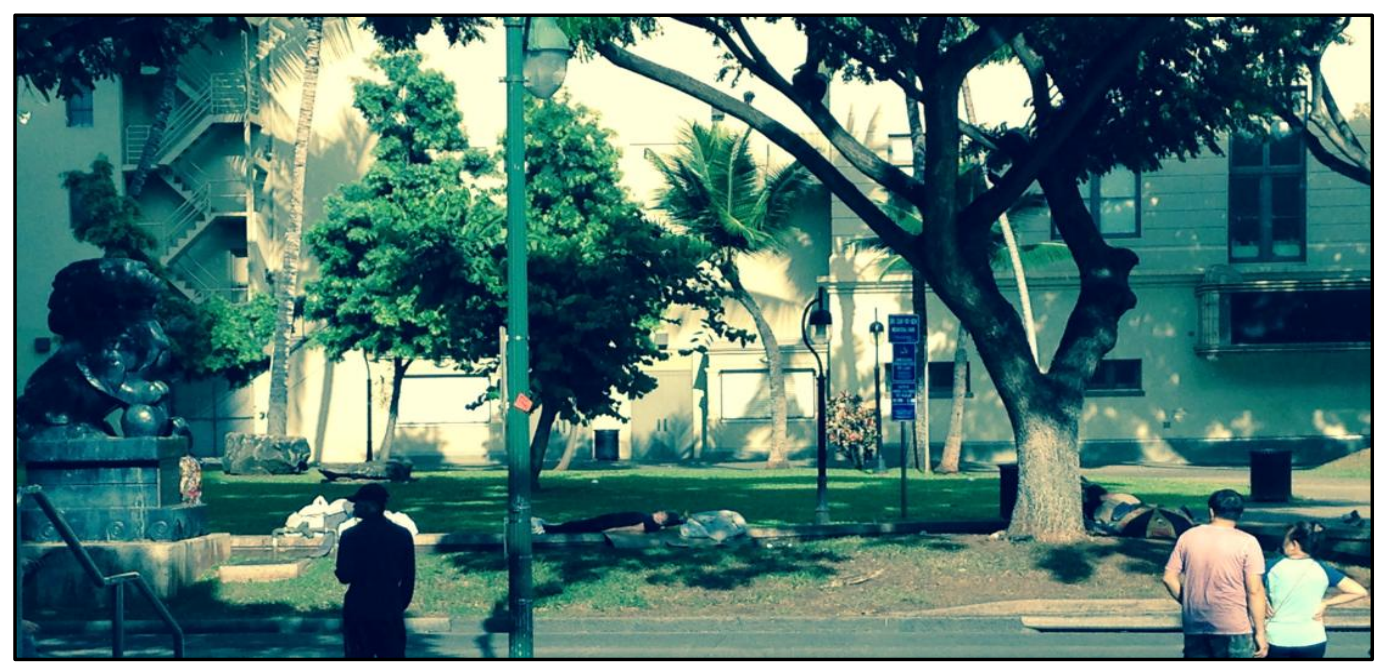

Figure 1. In Honolulu's Chinatown homeless sleep on the sidewalks as locals and tourists alike look on. Image courtesy of the author.

\section{A Slow-Motion Disaster, Decades in The Making}

That is not to say that homelessness is new in Hawai' $\mathrm{i}$. Consider, for example, that the Community Mental Health Act of 1963 - put into law at the Federal level - impacted many mental care facilities and resulted in the deinstitutionalization of many of their residents [6; 7]. As a result, many former institutionally cared-for patients ended up on the streets of urban centres across the US with little to no support structures to assist them. It was a harbinger of what was to come in the next three decades.

As a student in the mid-2000s at the University of Hawai'i, Mānoa (UHM) I and friends "couch surfed" with family, friends and occasionally classmates "camped" at the beach for weeks at a time, as well as knowing one postgraduate student friend who lived permanently in her vehicle. All of us worked, most had two or more jobs. Given the fact that Hawai'i has the highest rent in the nation according to the US Census Bureau $[9,10]$, it is hardly surprising that most of us would have fit into a category now labelled "housing insecure." A label that is applicable to some $50 \%$ of community college students across the US [8]. In the 2017 report, entitled "Hungry and in College: Results from a National Study of Basic Needs Insecurity in Higher Education" findings reflected that some 14\% of community college students across the US are homeless [8]. While in Hawai ' $i$, officials with the Department of Education reported in January of 2016 that nearly 3,576 students state wide were homeless. The point-in-time homeless count of the same year reflects just a little more than half of the Department of Education number, further underscoring the likelihood of a serve underrepresentation in the point-in-time count as was previously suggested by support service workers [3].

However, the homelessness on South King Street that I witnessed was far different from the hardships of my days at UHM. The situation was clearly desperate, pressing and chronic. And I wanted to know why had things gotten so bad while I'd been away - who were these people and why were they on the streets of Honolulu? The short answer to the "why" of this question of course involves the increasing gentrification of Honolulu combined with low-wages and high rents. The housing market is in international demand, and lower-waged employment in tourism dominates many workers earning 
potential. Consider that tourism is the largest single contributor to the state's gross domestic product (GDP) with visitors spending over $\$ 15.6$ billion in 2016, or $~ 25 \%$ of the economy, according to the Hawai' $i$ Tourism Authority [11]. On average rents in Hawai' $i$ increased by $45 \%$ during the period between 2005 and 2012, while average wages increased by only 21\% [12].

The longer answer to the above query stems, at least in part, from a positive correlation between increasing tourists and homeless rates, where many have been priced out of everything from a studio apartment to a cup of coffee. In addition, moving from correlation to direct causation we see that decades of cuts in public housing have compounded and manifested in the current crisis. In short, the homeless crises in Hawai' $i$ and much of the mainland US has its roots in the last century, with only the latest blow to public housing coming from the Trump administration. The US Department of Housing and Urban Development (HUD), overseen by Cabinet Secretary Dr Ben Carson, has released plans for fiscal year 2018 to cut low-income housing support funding by $\$ 16,470,143$ in Honolulu alone, with additional $\$ 6$ billion cuts planned nationwide [13].

\section{AN UNCOMFORTABLE SILENCE}

Let us now turn to the "who" of the Hawai'i homeless crisis. In 2008, a study conducted at the University of Hawai'i reflected that more than half the homeless receiving services in Hawai'i were not lifetime residents of the state, with $64 \%$ of those individuals having lived in Hawai' $i$ less than ten years [14]. Drawing on my own research and experiences in speaking with those in shelters, beach encampments and makeshift shelters on the streets, many of the above $64 \%$ were from the US mainland or Micronesian region of the Pacific. Nearly all I spoke with had experienced a series of unfortunate events, such as a loss of employment, a car accident, a broken limb or serious illness that had pushed them from precarious living situations onto the streets.

While I appreciated everyone who spoke with me, so generously sharing their thoughts, experiences and stories of hardship and success, I was especially moved by the stories of the Micronesian diaspora communities in Honolulu and Hilo. The most recent US Census data reflects that at least 20,000 Micronesians now live in Hawai'i [15], many thousands of which have met with success. In acknowledgement and appreciation of the rich languages, cultures and histories of this diverse part of Oceania, I would like to clarify my use of the word "Micronesia" or "Micronesian" as I may at times refer to the region of Micronesia (e.g. similarly to other regional and population descriptors, such as European and Melanesian); while all those that have an ancestral heritage from the islands which comprise the present-day Federated States of Micronesia (FSM) I also refer to as "Micronesian." Additionally, I refer to all those that have ancestral heritage from the present-day Republic of the Marshall Islands (RMI) as "Marshallese."

Contrary to popular stereotypes numerous COFA migrants I spoke with are successful entrepreneurs, educators and professionals, and all were deeply concerned with the success of the wider Micronesian diaspora and many were actively working on ways to further support their local community. I was also impressed with the hard work and passion of high school and university students in Honolulu and Hilo, many of whom I spoke with were actively planning on returning to their ancestral islands with ambitious plans to improve these communities. I sincerely hope these plans come to fruition as many of the islands and archipelagos of Micronesia are now dealing with pressing issues, ranging from climate change to cultivating sustainable development. Yet, there was one topic that when broached always brought our animated conversations and plans for the future to an uncomfortable silence. Without much surprise the subject no one wanted to discuss was that demographic data reflects some $\sim 20 \%$ of homeless individuals living in Honolulu are COFA migrants [7].

\section{4. "FOR THE GOOD OF MANKIND"}

Why are so many Pacific Islanders leaving their home islands in Micronesia to come to the US, even at the risk of an uncertain future? The answer to this query can in part be found on a sunny Sunday in February of 1946, with the visit of the Military Governor of the Marshall Islands, Commodore Ben Wyatt, to Bikini Atoll. Following church services, the Commodore asked the islanders in an open-air town hall meeting if they would be willing to leave their atoll for an unknown period of time so that the US could undertake nuclear-weapons testing. The departure from Bikini was to be temporary, though the exact period was never made clear to the islanders and the Commodore stressed that this was "for the good of mankind and to end all world wars" [20]. The 167 residents of the atoll considered what was being asked of them and after much debate, Juda, the leader of the Bikini people, 
declared that "We will go, believing that everything is in the hands of God" [20]. The nuclear testing in Micronesia would commence in March of 1946 with Operation Crossroads and leave a painful legacy that endures today.

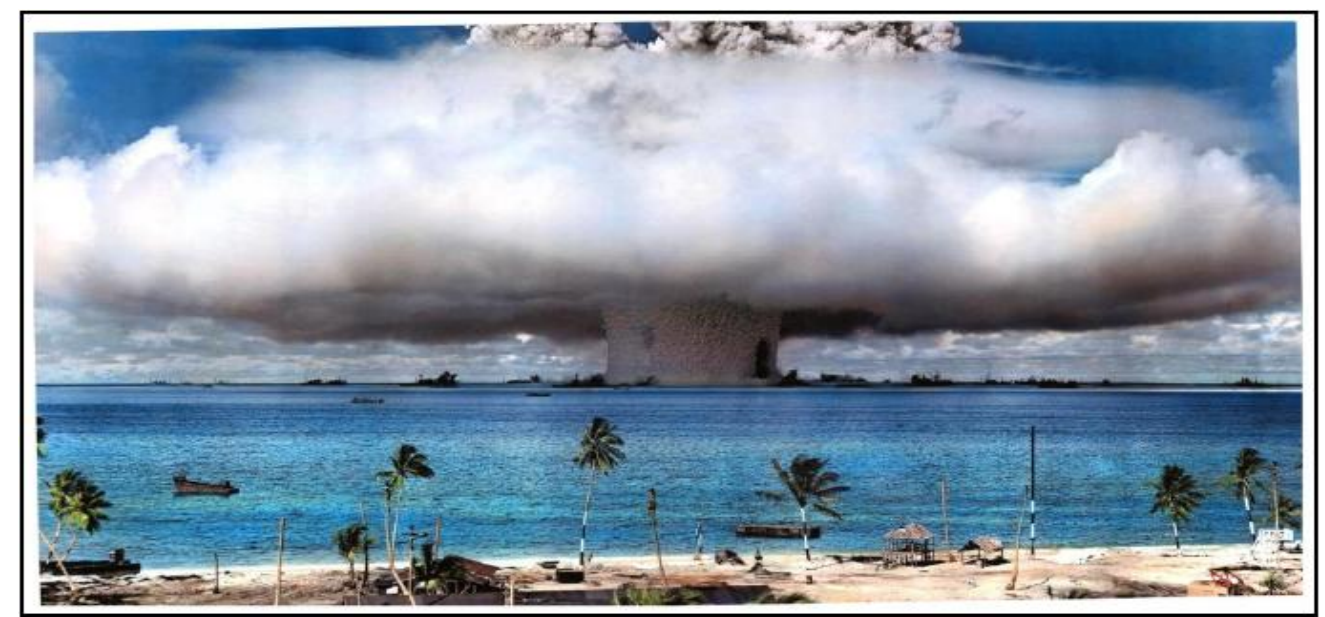

Figure 2. Baker Test, as part of Operation Crossroads, 25 July 1946 at Bikini Atoll, Marshall Islands. Crossroads involved some 42,000 men; 242 ships; 156 airplanes; 25,000 radiation recording devices; and 5,400 experimental rats, goats, and pigs [16; 24]. Image courtesy of the US Archives.

\section{5. "We've Got THE TruST, AND THEY'VE Got THE TerRITORY"}

In the aftermath of World War II, most of the islands in the geographic area of the Northwest Pacific Ocean known as Micronesia-which includes the Northern Marianas, Palau, Yap, Chuuk, Pohnpei, Kosrae, and the Marshall Islands - were held in trust by the US. Military leaders were fervent in their calls for the continuation of strategic strongholds in the Pacific by the US and the development of the trust. Henry Stimson, the then Secretary of War, maintained "they are not colonies; they are outposts," asserting that US annexation of Micronesia would be "merely the acquisition by the United States of the necessary bases for the defence of the Pacific for the future world" [17]. The United Nations issued a mandate known as "Trust Territory of the Pacific Islands" (TTPI).

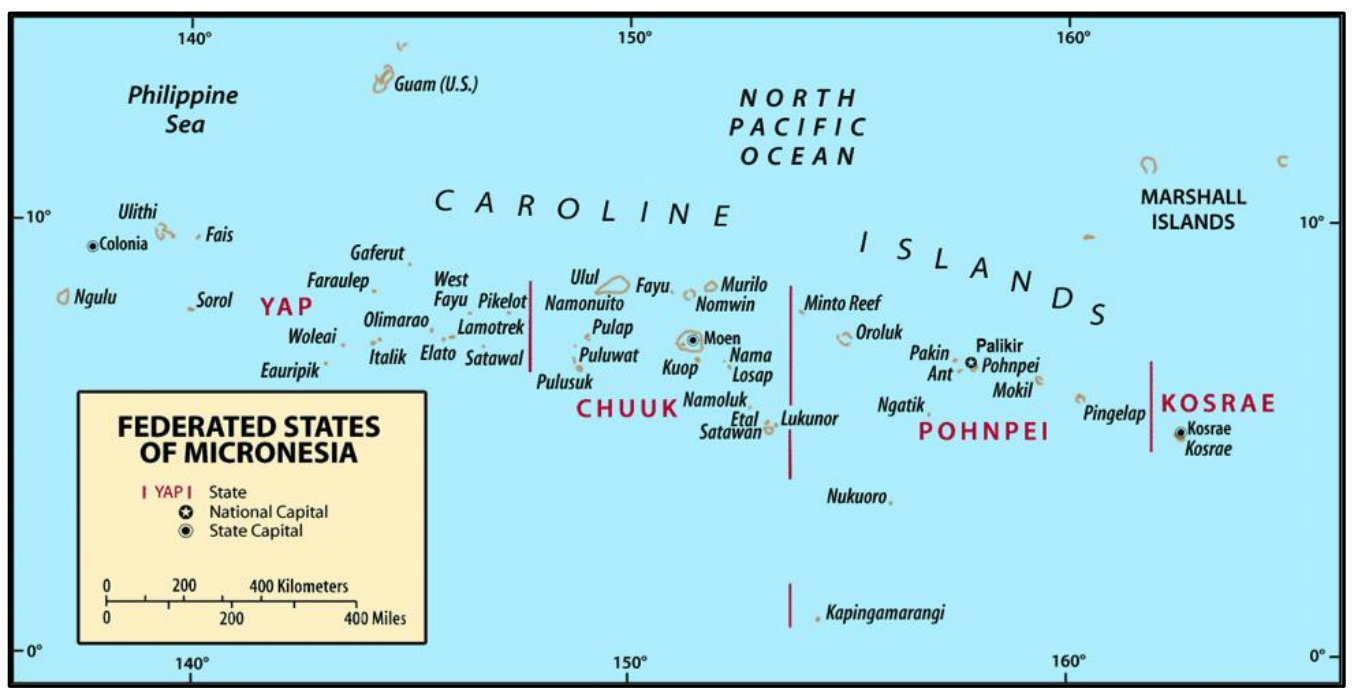

Figure 3. Map of the Federated States of Micronesia. Image courtesy of the Government of the Federated States of Micronesia [18].

From 1946 to 1958, the US tested 66 atomic and hydrogen weapons, or the equivalent of more than 7,000 Hiroshima-sized bombs in the Marshall Islands resulting in unprecedented destruction of the surrounding environment. To break it down even further, that's more than one Hiroshima-size bomb detonated every day. Six islands were vaporised by the weapons and hundreds of people were irradiated [19]. The nuclear testing and military activities dominated the focus of the first two decades of US administration in Micronesia, leading some to surmise "US policy towards the islands could best be described as one of benign neglect. In fact, there was no policy" [16]. "Benign neglect" is 
rather generous, all things considered. As Rubon Juda, a former resident of Bikini Atoll describes the Islanders' harsh reality following their relocation from Bikini Atoll to Rongerik Atoll in 1946:

Another problem we encountered was that we had no source of income. We couldn't make copra, and only the women could make a little money from the selling of their handicrafts to the Americans when they visited us on the island, so we continued to starve. After some time, and a tremendous amount of suffering, there came an American man, Dr Leonard Mason [an anthropologist from the University of Hawai'i], who brought us some food. He understood that we were starving and he could tell that we were in trouble, even dying. He encouraged us to begin discussing among ourselves other alternatives to Rongerik Atoll [20].

In total, more than $\$ 20$ billion was spent on the nuclear weapons testing at Bikini and Eniwetok. However, the annual budget of the Trust Territory averaged around just $\$ 5$ million with little being put toward economic development of the territory [20]. In response to UN Trusteeship Council's first visit to the region - and a decidedly critical report regarding US administrative duties - the circumstances began to improve in the summer of 1961 [16]. President Kennedy would go on to address the United Nation's General Assembly in 1961 and emphasized the "continuing tide of selfdetermination," as well as a further confirmation of "the peaceful, expeditious movement of nations from the status of colonies to the partnership of equals" [21].

The following two decades saw further political developments around the Trust Territory with the Commonwealth of the Northern Marianas Islands (CNMI) and the three Freely Associated States (FAS): Republic of Palau (ROP), Republic of the Marshall Islands (RMI), and the Federated States of Micronesia (FSM) — which includes Yap, Chuuk, Pohnpei and Kosrae-forming separate COFAs. Indeed, the movement of these island nations into free association in the 1980s with the US has been suggested as little more than a movement "from covert colonialism to overt dependence and military accommodation" [16]. Consequently, one would be hard pressed to summarized the situation better than Marshallese Senator Ataji Balos who once quipped-"We've got the trust, and they've got the territory" [16].

\section{A PAinful Inheritance}

We know that "the Pacific Island region has been used as the First World's nuclear weapons laboratory and intercontinental ballistic missile testing range for over fifty years. Nuclear activityconsisting of hundreds of nuclear detonations - has occurred almost continuously from 1946 to 1996, and intercontinental missile testing continues today.... six islands were vaporized and fourteen others were left uninhabitable" [19]. In addition to the well-known weapons testing, a controversy remains regarding the deliberate exposure of human populations (Marshallese and military personnel) following the Castle Bravo nuclear test at Bikini Atoll in 1954, which had an unexpectedly high level of fallout.

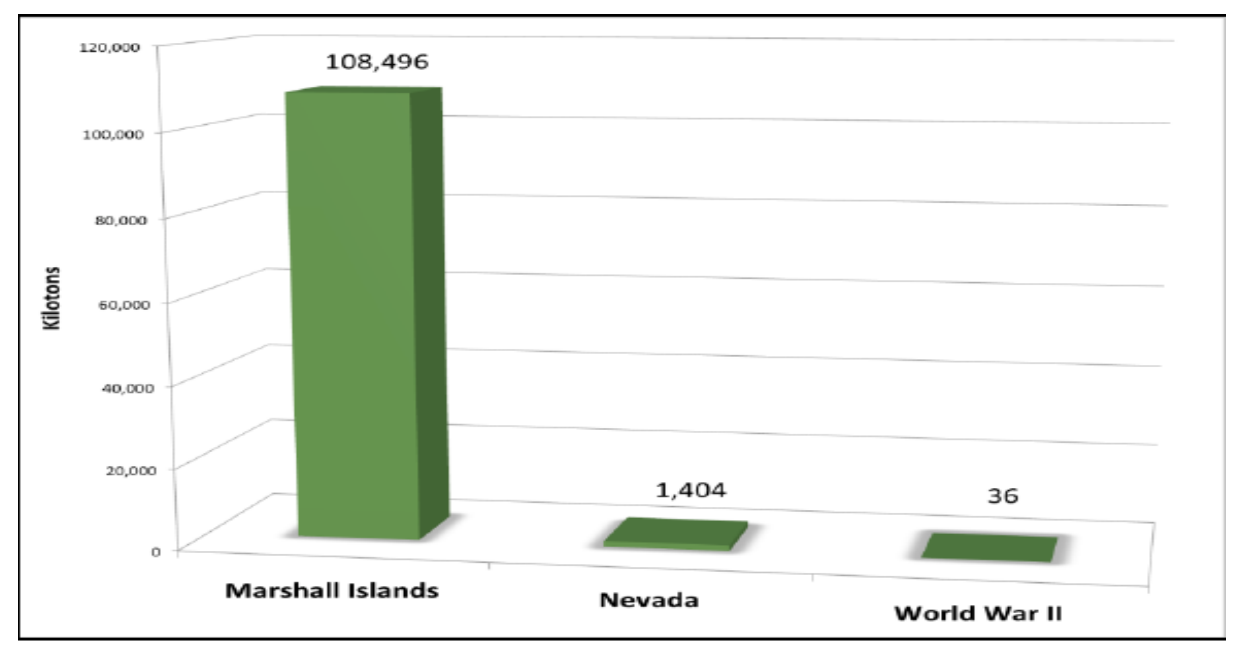

Figure 4. Chart of Nuclear Weapons Yields in the Marshall Islands, Nevada, and all of World War II [22].

The US government continues to attest the that the fallout was the result of a serious miscalculation. Putting aside if it was deliberate or not (which I appreciate is a massive aside) what is clearly known 
and documented is that the US government studied and chose to conduct additional medical experiments on the survivors of Bravo, without ever obtaining their informed consent. This medical study became known as Project 4.1 - the "Study of Response of Human Beings exposed to Significant Beta and Gamma Radiation due to Fall-out from High-Yield Weapons." Under the pretence of following those impacted from their initial exposure, the physicians of Project 4.1, from 1961 to 1966, conducted chromium-51 and tritium experiments on the Marshallese exploring how the human body responded to radioisotopes $[23 ; 25]$.

Formerly classified correspondence among researchers, with their offhand remarks preserved for posterity, was freely available on the Internet until 2004. In one letter from 1961...Dr Robert A. Conrad, the director of the medical research [project]...suggested, "I suppose we could try it on the unexposed people." Such cavalier attitudes regarding the health and well-being of Marshallese people are clear reflections of racist attitudes [23].

In 1972 the Bikinians returned to their home atoll in the follow-up to the Atomic Energy Commission, under the Johnson administration, determining the atoll was again safe for habitation [26;20]. In the twenty-six years since their original departure from the atoll much had changed with extensive environmental degradation, yet they were delighted to be home [20]. This happy return was not to last. In 1975 radiologic testing was carried out that indicated elevated radioactivity in the air, soil and locally grown food. Restrictions on the intake of locally grown food were put in place, but by 1978 the entire atoll was again deemed unsafe for habitation and the Bikinians were relocated to another island once again [20]. It has been argued that the "US government was fully aware of the persistent radiation on Bikini when it resettled people to their home island. Once the US government resettled the community, it treated the people's exposure to radiation as an important scientific opportunity" [27]. Regardless if there were those in the US government and military fully aware of the true nature of the situation on Bikini or not, the prolonged delay in response and relocation of the Bikinians is deeply concerning and reflects gross negligence on the parts of the US government and military administrators [28].

From more recent academic medical studies we know the physiological and medical history of those exposed to nuclear testing, let alone the staggering yield amounts in Figure 4, is indeed a painful one. Though it should be noted no single individual's health can conclusively be attributed to nuclear fallout as health is composed of a great many factors, including physical environment, nutrition, socio-economic levels, education, gender, access to health services and so on. However, the facts are these: we know that cervical cancer is the primary cause of death from cancer for women in Chuuk, FSM [29], and "cervical cancer mortality in Marshallese women is sixty times higher than in the United States, male liver cancer rates thirty times US levels, breast and gastrointestinal cancer rates five times the US rate, and lung cancer threefold higher" [30]. Furthermore, a 2004 National Cancer Institute study surmised that the nuclear tests would likely result in 532 radiation-related cases of cancer among the 13,940 Marshallese alive in the 1950s [31]. Perhaps most poignant and painful of all the radiation illnesses studied, is the horrifying phenomenon of "jellyfish babies" where pregnancies result in births with severe abnormalities - "some babies that were born resembled bunches of grapes"-and stillbirths [27]. Consequently,

$[R]$ esearch on health effects of exposure to radiation from nuclear weapons involved gross violations of human rights of people of the Marshall Islands...[a]s a matter of social justice, in order to ensure the human right to health, the federal government should extend Medicaid eligibility to all Micronesian people from the Compact of Free Association nations [23].

The critical shortage of adequate general health care facilities, let alone specialist centres for a range of medical conditions including diabetes and cancer, is drawing many from Micronesia to the US. This is corroborated in a 2010 survey of 2,522 Micronesians in Hawai'i with the most frequently cited reason for migrating being health care (35\%), (followed closely by education at 33\% and employment opportunities at 22\%) [43]. Yet, the COFA migrants find themselves caught in a terrible form of structural violence, or a wilful institutional catch-22, wherein as they are not US citizens and technically non-immigrants, they do not qualify for many federal programs, such as Medicaid and Social Security. This means many COFA migrants are not able to access full healthcare and support 


\section{A Rowan Gard}

services in the US. The very medical care many need most desperately, and the very reason many have travelled thousands of miles across the Pacific in the first place, has been denied or truncated at times.

In the last two decades there has been a revolving door when it comes to full healthcare and support services access for COFA migrants. For example, under Hawai'i Governor Linda Lingle's administration in 2010 COFA migrants were removed from Medicaid healthcare access. This was later overturned in court over the denial of equal protection of the laws (i.e. the Fourteenth Amendment to the US Constitution) and in 2014, under Governor Neil Abercrombie, Hawai' $i$ spent $\$ 163$ million on COFA support in the form of social services, education and health care, while receiving only \$11 million a year in "Compact-Impact Aid" from the federal government [30]. Expanded federal funding is desperately needed and political leaders in Hawai' $i$ and Guam have pursued funding, including introducing the Compact Impact Aid Act of 2015 to Congress, with few results. All things considered, it is unsurprising, though no less troubling, that there seems little political will in Congress to increase aid or indeed discuss the extension of COFA past 2023.

The advent of more reasonably priced health insurance plans under the Affordable Care Act, more commonly known as Obamacare, has opened up healthcare to many, and in 2017 there has been a push to enrol as many COFA migrants living in the US as possible in the programme [32]. Yet, the ongoing political climate in the Republican-controlled Congress surrounding Obamacare and the Trump administration's ongoing efforts to repeal it, make Obamacare's future, as well as millions of American's access to healthcare, uncertain. It is vital to note the lack of any real concern at the highest levels of US government, as typified by Secretary of State, Henry Kissinger, whose concern in the 1970s over Micronesia consisted of the following - "There are only 90,000 people out there. Who gives a damn?" [33]. These callous sentiments all too often reflect the US government's regard, under various Presidents, for those in desperate situations in perceived of far-off places, whether the crisis be a result of nuclear fallout, extreme weather events, war, climate change or closer to home (perhaps even just down the street) the escalating homeless crisis.

\section{7. "DRY OUR TEARS OF SORROW WITH DOLLAR BILLS"}

"We've learned to dry our tears of sorrow with dollar bills. But money never takes the place of Bikini" reflected Lore Kessibuki, a noted storyteller and former resident of Bikini Atoll in conversation with a New York Times journalist in the late 1970s [20]. The COFA nations currently receive $\sim \$ 200$ million in direct aid from the federal government in exchange for strategic access to the $\sim 1.7$ million nautical miles of Micronesian ocean [30]. These waters account for a "majority of the trade and energy commodities transiting through Asia. With approximately one-third of the global trade and nearly 50 perfect of energy commerce passing through the region, it's understandable why the US security interests maintain visibility on FSM" [34]. Another fact that is especially concerning is that the COFA funding is currently slated to end in 2023. If the federal funding were to stop it is safe to surmise that COFA nations' economies which are mainly structured around this aid (following the US government's inference in and breakdown of indigenous subsistence economies [42]), would be thrown into chaos resulting in deeper levels of poverty [35].

Although several national and international tribunals have determined that the US government's negligence did indeed violated the human rights of the Bikinians, they have never received just compensation. "On March 5, 2001, the Nuclear Claims Tribunal of the Marshall Islands awarded the Bikinians a total of $\$ 563,315,500$ on top of all the compensation paid by the US to the Bikinians prior to 2001" [20]. Regrettably the tribunal remains under-funded and so the awarded financial compensation remains unpaid to the Bikinians. Consider too that "a comparison with the U.S. testing in Nevada (and subsequent compensation program) reveals that despite facing much higher levels of exposure and contamination, the Marshallese have actually been compensated at a lower rate... in comparison to their American counterparts" [22]. Furthermore, "the average payment to an American victim was $\$ 63,500$ as compared to $\$ 34,556$ to Marshall Islanders, despite the explosive yield at the Marshall Islands being ninety-three times greater than the combined yield of all the tests conducted in Nevada" (as seen in Figure 4) [22]. Estimates of the area affected within Micronesia indicated that area size could be on a magnitude of as much as four times greater than the area in Nevada [28].

Micronesians and Marshallese have come in greater numbers to the US than those from Palau or Guam in greater Micronesia, in part because both Palau and Guam have stronger economies. Shifting 
from macroeconomics to microeconomics, the various and important contributions Micronesians and Marshallese make to Hawai'i's economy is often ignored in the media and public discourse. "Little has been mentioned about Micronesians' varied contributions to Hawai'i's economy. Direct economic contributions are estimated to be $\$ 50$ million annually-in generated income, state income tax, expenditures, and compact impact assistance" [36]. Beyond the purely economic contributions, citizens of FSM serve in the US military in great numbers with one study noting a service rate "at approximately double per capita rate of American citizens" [37]. Poignantly many Micronesians, despite not being full citizens, have made the ultimate sacrifice for the US, as more FSM soldiers have perished in the line of duty in Iraq and Afghanistan per capita than any US state.

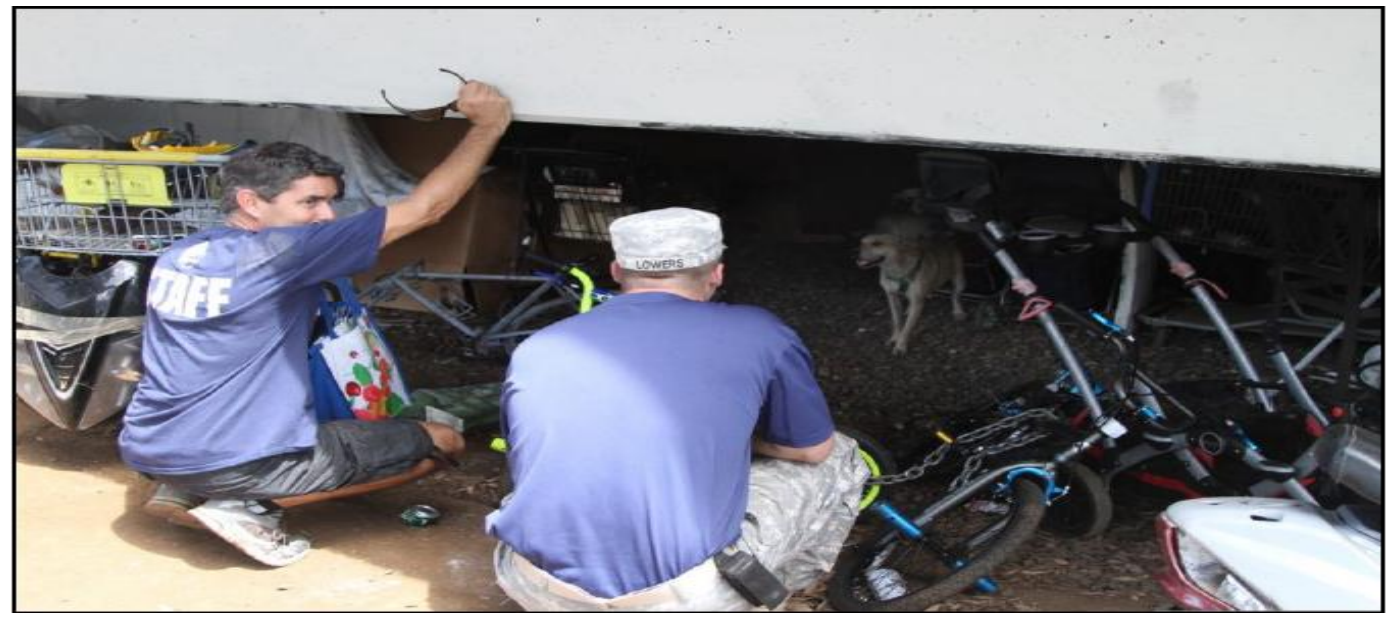

Figure 5. A staff member with the Institute for Human Services Men's Shelter and US Army Staff Sgt. Gaelen Lowers, speak with a homeless veteran during the Soldier for Life Veteran outreach programme in Honolulu, June 2013. The 2017 midyear point-in-time count found 449 veterans homeless on O'ahu, up 9\% from 413 in 2016 [38]. Image courtesy of Sgt. Tiffany Fudge.

As a great many citizens of Hawai'i proudly call themselves "mixed plates," with a tendency to think we are past racism in Hawai' $i$, and that we are evolved and free of such prejudices, this is regrettably untrue. Discrimination, racism, prejudice, racially motivated vandalism and hate-crimes are all present in Hawai' $i$ and focused on Micronesians [41]. Racism takes subtler forms as well, such as the denial of a rental or job application or a general feeling of not being welcome in a public place, that are not as easily measured or reported. For example, in my own visits to the Kaka'ako Waterfront Park homeless encampment in 2015 and 2016 (one of the largest homeless encampments on O'ahu with around 300 residents at the time) I noted self-imposed segregation. The encampment was home to dozens of Micronesians, most of whom clustered their shelters together and were separated from the local homeless. It was a community within a community, an island on an island in the most isolated archipelago in the world.

As increasing numbers of COFA migrants, especially those from more rural areas, make their way to US urban centres looking for work (largely owing to struggling economies and climate-changeimpacted natural resources at home) many find themselves unprepared for urban life. But despite facing immense challenges in accessing housing, healthcare and education, all the while overcoming prejudice, COFA migrants are meeting with hard-won success. As Asterio Takesy, Ambassador to the US from FSM, points out "our citizens are 90\% employed, the ones that are not employed are either taking care of kids or are in school. We are trying our best... and I am seeing an upward mobility" [32]. However, given the extreme levels of income inequality in the US [40], is real upward mobility a thing of the past?

\section{KNOWING The PASt, Shaping The FUtURe}

In the Value of Hawai' $\mathrm{i}$-Knowing the Past, Shaping the Future Trisha Kehaulani Watson wisely notes that "addressing homelessness is not about rehabilitating individuals, it is about rehabilitating our community" [7]. This of course is far easier said than done, sadly given the lack of political will in adequately dealing with the homeless crisis at the highest levels of government and the troubling levels of ever rising income inequality. While there is some positive change in the most recent homeless point-in-time count undertaken in May 2017, which reflects a $14 \%$ decrease in familial homelessness on $\mathrm{O}^{6} \mathrm{ahu}$, the overall trend is one of increased homelessness [38]. This trend is likely 
to continue taking into account the Trump administration's current plans to cut some 6 billion from HUD in 2018 [13], and the ever-increasing and deeply troubling rates of income inequality in the US, as illustrated in Figure 6.

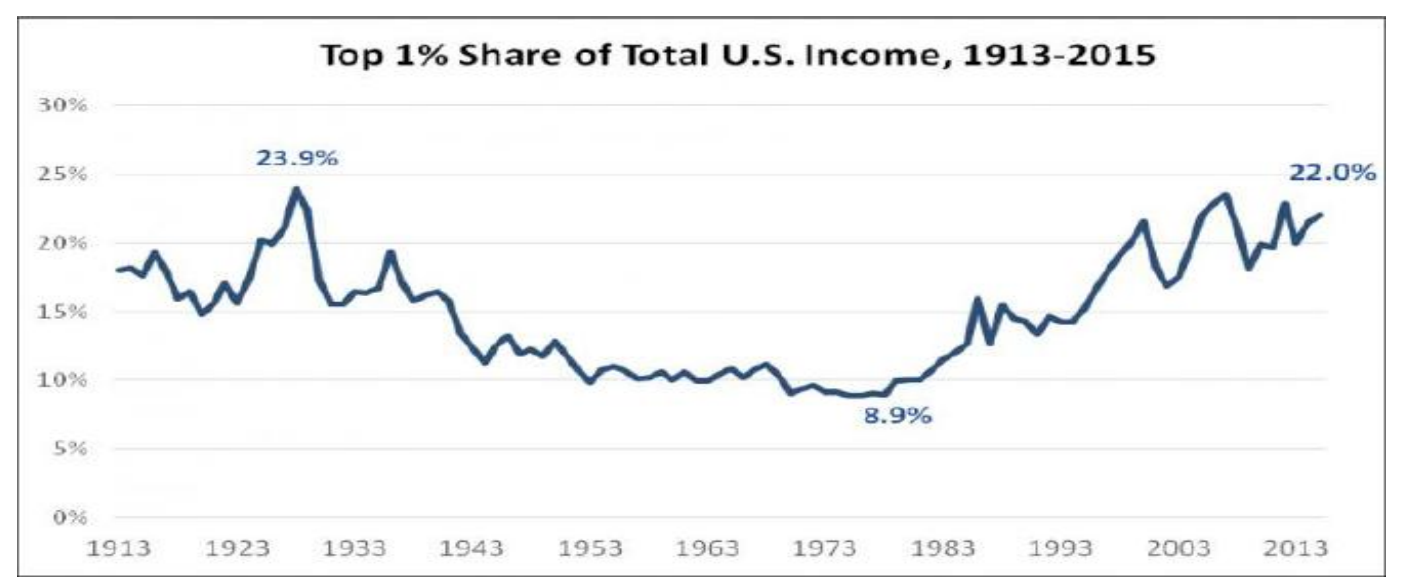

Figure 6. The top 1\% of America's income earners have more than doubled their share of the nation's income since the middle of the $20^{\text {th }}$ century. The last time American top $1 \%$ incomes reached a similar peak was in the late 1920s, right before the onset of the Great Depression. Image courtesy of Inequality.org [39, 40].

The high levels of income inequality are especially alarming, as more and more wealth is concentrated in the hands of a few, the fairness of political institutions and economic systems for the many are at risk of being significantly undermined. Simply put, all those in the lower and middle classes have to work harder and harder to stay in place on an increasingly tilted playing field — it is the Red Queen hypothesis on a national scale. There are a number of measures that would assist all those in danger of displacement and slipping (further) into precarious situations in Hawai'i or the US mainland:

- Urge Congress to rethink the $2018 \$ 6$ billion cuts to HUD;

- Advocate for greater power and increased federal funding to states working to support the chronically mentally ill;

- Press Congress to legislate the tenets of the Compact Impact Aid Act of 2015;

- Create tax credits for those caring for elderly parents and family members in their home; and

- Push for full access to Medicaid and Children's Health Insurance Program (CHIP) for all COFA migrants and as well as establish adequate medical facilities in Micronesia.

So then what comes next? Well, that is one giant question mark.

\section{ACKNOWLEDGEMENTS}

My research was generously made possible by Dr Tony Crook with funding from the University of St Andrews and was further supported by the European Consortium for Pacific Studies (ECOPAS) with funding from the European Union (EU). I am deeply grateful to the Micronesian diaspora communities in the Honolulu and Hilo areas that so generously shared their stories with me, most especially the students at the University of Hawai' $i$, Hilo with the Center for Pacific Island Students. I owe a debt of gratitude to Drs Vidalino Raator and Joeseph Gentz with University of Hawai'i, Hilo for their support and friendship these many years. A heartfelt thanks to Jermy Uowolo and all those from Micronesians United-Big Island who so kindly made time to share their thoughts, experiences and insights with me. And I remain deeply impressed with the magnificent staff of Goodwill Services in Hilo and am thankful for the time I spent with them. I am grateful too to Kimo Calvara with the Institute for Human Services for so generously sharing his thoughts and time with me. I would be remiss if I did not also thank Josie Howard and the wonderful staff of We are Oceania for all that they do. And a special thank you to Dr Chad Blair with Honolulu Civil Beat for so kindly sharing his knowledge of socioeconomic issues and politics in the Pacific. Lastly, I thank Steven Fraser and Ricky Young for their support, friendship and comments on earlier drafts of this article.

\section{REFERENCES}

[1] National Alliance to End Homelessness. (2016). Homelessness: A State of Emergency Do Local Decisions Have National Implications? February 2016. Online. http://www.endhomelessness.org/page//files/Home lessness_A\%20State\%20of\%20Emergency_2.pdf. Pp.2-4. Accessed 25 January 2017 
[2] Associated Press. (2015). Hawaii governor declares state of emergency among homeless crises. The Guardian. 17 October 2015. Online. https://www.theguardian.com/us-news/2015/oct/17/hawaiihomelessness-state-of-emergency. Accessed 20 January 2017.

[3] Hawaii News Now. (2016). Report: Hawaii Homeless Population Continues to Grow. 29 June 2016. Online.http://www.hawaiinewsnow.com/story/32339229/number-of-homeless-in-hawaii-grows-to-7600. Accessed 25 January 2017.

[4] Associated Press. (2017). Amid booming economy, homelessness soars on the US West Coast. 9 November 2017. Online. https://apnews.com/d480434bbacd4b028ff13cd1e7cea155. Accessed 20 November 2017.

[5] Bussewitz, C. (2015). Hawaii struggles to deal with rising rate of homelessness. Los Angeles Times. 15 November 2015. Online. http://www.latimes.com/nation/la-adna-hawaii-homeless-20151115-story.html. Accessed 18 January 2017.

[6] Associated Press. (2013). Kennedy's Vision for Mental Health Never Realized. USA Today. 20 October 2013. Online. https://www.usatoday.com/story/news/nation/2013/10/20/kennedys-vision-mental-health 13100001/. Accessed 12 February 2017.

[7] Watson, T. (2010). Homelessness in In the Value of Hawai 'i-Knowing the Past, Shaping the Future. Edited by Craig Howes \& Jon Osorio. Honolulu: University of Hawai' ${ }^{i}$ Press.

[8] Goldrick-Rab, S., Richardson, J. \& Hernandez, A. (2017). Hungry and Homeless in College: Results from a National Study of Basic Needs Insecurity in Higher Education. http://wihopelab.com/publications/ Hungry-and-Homeless-in-College-Report.pdf. Wisconsin Hope Lab. Accessed 25 February 2017.

[9] Eagle, N. (2016). Hawaii Rent Highest in Nation. Honolulu Civil Beat. 15 September 2016. Online. http://www. civilbeat.org/2016/09/census-hawaii-rent-highest-in-nation/. Accessed 25 February 2017.

[10] United States Census Bureau. (2015). Hawaii-Median gross rent 2011-2015. Online. https://www.census .gov/quickfacts/table/HSG860215/15. Accessed 25 February 2017.

[11] Hawai'i Tourism Authority. (2016). Fact Sheet: Benefits of Hawai' $i$ 's Tourism Economy. Online. http://www.hawaiitourismauthority.org/default/assets/File/HTA\%20Tourism\%20Econ\%20Impact\%20Fact $\% 20$ Sheet\%20(with\%20December\%202016\%20data).pdf. Accessed 20 November 2017.

[12] Hawaii Appleseed Center for Law and Economic Justice Policy. (2014). Report: The High Cost of Our Affordable Housing Shortfall. Online. http://www.hiappleseed.org/sites/default/files/Hi\%20Appleseed $\% 20$ Housing\%20Crisis\%20Report.pdf. Accessed 3 March 2017.

[13] Affordable Housing Online. (2017). Impact of the Trump/Carson HUD Budget Cuts in Honolulu, Hawaii. https://affordablehousingonline.com/FY18-HUD-Budget-Cuts/Hawaii/Honolulu. Accessed 20 November 2017.

[14] University of Hawaii Center on the Family. (2010). Homeless Service Utilization Report. Online. http://uhfamily.hawaii.edu/publications/brochures/HomelessServiceUtilization2010.pdf. Accessed 28 February 2017.

[15] United States Census Bureau. (2015). Hawaii Population Demographics. Online. https://www.census.gov /quickfacts/table/HSG860215/15. Accessed 25 February 2017.

[16] Weisgall, J. (1985). Micronesia and the Nuclear Pacific Since Hiroshima. SAIS Review, 5 (2), SummerFall, pp. 41-55. Johns Hopkins University Press.

[17] United States, Department of State. (1955). Foreign Relations of the United States: Diplomatic Papers, Conferences at Malta and Yalta 1955: 78-81. Online. https://history.state.gov/historicaldocuments/ frus1945 Malta. Accessed 15 March 2017

[18] Government of the Federated States of Micronesia. Online. http://fsmgov.org. Accessed 10 March 2017.

[19] Kuletz, V. (2002). "The Movement for Environmental Justice in the Pacific Islands." In The Environment al Justice Reader: Politics, Poetics, \& Pedagogy, Pp. 125-142. Tucson, AZ: University of Arizona Press.

[20] Niedenthal, J. (2001). For the Good of Mankind: A History of the People of Bikini and their Islands. Majuro: Bravo Books.

[21] John F. Kennedy Speeches. (1961). Address before the General Assembly of the United Nations, September 25, 1961. Online via the John F. Kennedy Library and Museum Archives. https://www.jfklibrary.org/Research/Research-Aids/JFK-Speeches/United-Nations_19610925.aspx

[22] Harvard Law Student Advocates for Human Rights. (2006). An Evaluation of Continuing US Obligations Arising out of the US Nuclear Weapons testing Program in the Marshall Islands. Harvard Law School.

[23] Yamada, S. \& Akiyama, M. (2014). "For the Good of Mankind": The Legacy of Nuclear Testing in Micronesia. Social Medicine, 8 (2). Pp. 83-92. University of Hawai'i. 
[24] Weisgall, Jonathan. (1994). Operation Crossroads: The Atomic Tests at Bikini Atoll. Annapolis, Md: Naval Institute.

[25] Conard, R., Meyer, L., Sutow, W., Lowrey, A., Cannon, B., Moloney, W. et al. (1963). Medical Survey of the People of Rongelap and Utirik Islands Nine and Ten Years After Exposure to Fallout Radiation. Upton, NY: Brookhaven National Laboratory, Unites States Atomic Energy Commission.

[26] Kiste, Robert C. (1974). The Bikinians: A Study in Forced Migration. Menlo Park: Cummings Company.

[27] Barker, H. (2004). Bravo for the Marshallese: Regaining Control in a Post-Nuclear, Post-Colonial World. Belmont, CA: Wadsworth/Thomson.

[28] Johnson, Giff. (2009). Nuclear Past, Unclear Future. Majuro: Micronitor.

[29] Yamada, S. \& Pobutsky, A. (2009). Micronesian Migrant Health Issues in Hawaii: Part 1: Background, Home Island Data, and Clinical Evidence. Californian Journal of Health, 7(2), Pp. 16-31.

[30] Blair, C. (2014). The Micronesians Special Report Series. Honolulu Civil Beat. Online. http:// www.civilbeat.org/2015/10/an-untold-story-of-american-immigration/. Accessed 17 November 2017.

[31] National Cancer Institute. (2004). Estimation of the Baseline Number of Cancers Among Marshallese and the Number of Cancers Attributable to Exposure to Fallout from Nuclear Weapons Testing Conducted in the Marshall Islands. Online. http://marshall.csu.edu.au/Marshalls/html/Radiation/NCI-report.pdf. Accessed 17 November 2017.

[32] Blair, C. (2017). COFA Health Coverage Urged. Honolulu Civil Beat. 10 November 2017. Online. http://www.civilbeat.org/2016/11/cofa-health-coverage-urged/. Accessed 12 November 2017.

[33] Davis, S. (2014). The Empire's Edge: Militarization, Resistance, and Transcending Hegemony in the Pacific. Geographies of Justice and Social Transformations 21. University of Georgia Press.

[34] Matelski, T. (2016). Amererica's Micronesian Problem. The Diplomat. 19 February 2016. Online. http://thediplomat.com/2016/02/americas-micronesia-problem/. Accessed 10 February 2017.

[35] Cook, P. \& Kirkpatrick, C. (1998). Labor Market Adjustment in Small Open Economies: the Case of Micronesia. World Development, 26(5). Pp. 845-855. Great Britain.

[36] Falgout, S. (2012). Pohnpeians in Hawai' i: Refashioning Identity in Diaspora. Pacific Studies, 35(1/2). Pp. 184-202.

[37] Hawaii Appleseed Center for Law and Economic Justice Policy. (2011). Report: Broken Promises, Shattered Lives: The Case for Justice for Micronesians in Hawai ' $i$. Online. http://www.hiappleseed.org /sites/default/files/COFA\%20ReportFinal12-14-11.pdf. Accessed 27 February 2017.

[38] Partners in Care: Oahu's Continuum of Care. (2017). Point in Time Count. 10 May 2017. Online. http://www.partnersincareoahu.org/2017-point-time-count. 20 November 2017.

[39] Saez, E. (2016). Striking it Richer: The Evolution of Top Incomes in the United States. University of California, Berkeley. Online. https://eml.berkeley.edu/ saez/saez-UStopincomes-2015.pdf. Accessed 10 November 2017.

[40] Inequality.org. (2017). Income Inequality in the United States. Online. https://inequality.org/facts/incomeinequality/. Accessed 15 November 2017.

[41] Perrone, P. (2017). Criminal Justice Data Brief. Crime Prevention \& Justice Assistance Division. Hate Crimes in Hawaii, 2016. Online. https://ag.hawaii.gov/cpja/files/2017/03/Hate-Crimes-in-Hawaii2016.pdf. Accessed 10 November 2017.

[42] Sutoris, P. (2011). Social Justice, Environmental Sustainability and the Relocation of the Bikinians, 19461978. The World Outlook (39). Pp.30-42.

[43] Riklon, S., Alik, W., Hixon, A. \& Palafox, N. (2010). The "Compact Impact" in Hawaii: Focus on Health Care. Hawaii Medical Journal. June;69( 6 Supplement 3):7-12. Online. https://www.ncbi.nlm.nih.gov/ pubmed/20539994. Accessed 10 November 2017.

Citation: A Rowan Gard. "Looking for Light on the Dark Side of the American Dream-Exploring the Painful Legacy of Nuclear Colonialism in Paradise." International Journal of Research in Sociology and Anthropology (IJRSA), vol 3, no. 4, 2017, pp. 1-11. doi:http://dx.doi.org/10.20431/2454-8677.0304003.

Copyright: (C) 2017 Authors. This is an open-access article distributed under the terms of the Creative Commons Attribution License, which permits unrestricted use, distribution, and reproduction in any medium, provided the original author and source are credited. 